\title{
Study on Groundwater Recharge Based on Chloride Mass Balance and Hydrochemistry in the Irrigated Agricultural Area, North China Plain
}

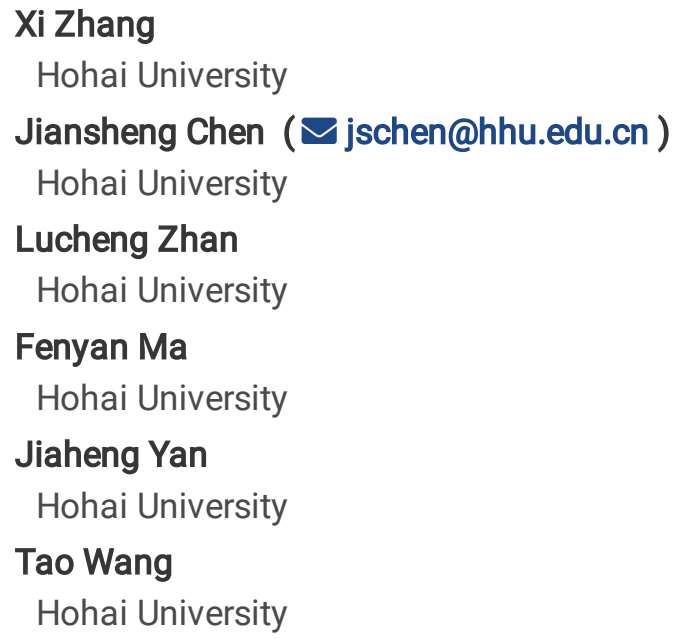

\section{Research Article}

Keywords: North China Plain, Unsaturated zone, Hydrochemistry, Stable isotope, Chloride mass balance

Posted Date: August 20th, 2021

DOI: https://doi.org/10.21203/rs.3.rs-782200/v1

License: (c) (i) This work is licensed under a Creative Commons Attribution 4.0 International License. Read Full License 


\section{Abstract}

In the North China Plain, water shortage seriously restricts economic development, and agricultural irrigation depends heavily on groundwater extraction. Irrigation water and precipitation may directly recharge to groundwater in the irrigated agricultural region. Therefore, calculating the recharge of precipitation and irrigation to groundwater is essential for the sustainable utilization of water resources. Furthermore, determining the transformation relationship of precipitation-soil watergroundwater is helpful to understand the hydrological cycle process better. The average groundwater recharge calculated by the chloride mass balance method is between 66 and $144 \mathrm{~mm} / \mathrm{yr}$, accounting for only $7 \%-17 \%$ of the total precipitation and irrigation water. The hydrogen and oxygen isotopes reveal that precipitation only affect soil water in topsoil, and soil water in deep soil is recharged upward by groundwater. Hydrochemical composition of soil water shows high concentrations of solutes in unsaturated zones. Infiltration water dissolves solutes through the unsaturated zone and brings them into the shallow groundwater, causing the deterioration of shallow groundwater quality. Therefore, reducing the recharge of precipitation and irrigation to groundwater by controlling the groundwater level and the intensity of single irrigation is recommended to protect groundwater quality. These results contribute to the effective management of groundwater resources and the control of agricultural pollution in groundwater.

\section{Introduction}

The North China Plain is one of the most densely populated economic belts and the most developed industrial and agricultural production area. However, water resources are scarce, and the per capita water is only $335 \mathrm{~m}^{3} / \mathrm{a}$, far below the baseline of global water pressure (1700 $\mathrm{m}^{3} / \mathrm{a}$ ) (Zhang, 2020). Therefore, industrial, agricultural and urban water demand largely depends on groundwater exploitation. In recent years, with the development of urbanization and improved living standards, water demand has increased sharply. Therefore, calculating the groundwater recharge from precipitation and irrigation is essential for the sustainable utilization of groundwater. Furthermore, determining the transformation process of precipitation-soil water-groundwater is helpful to understand the hydrological cycle better.

The methods of evaluating groundwater recharge include the groundwater level fluctuation method (Healy, 2002), the water balance method (Chen, 2003(b)), the soil water flux method (Kendy, 2003; Kendy, 2004), and the numerical simulation method (Min, 2015). Most of these methods require many or long sequences of hydrogeological parameters (precipitation, evaporation, runoff, and groundwater level), which are highly variable and difficult to obtain. The tracer method generally only requires a short sequence of data (Yuan, 2012; Wang, 2006). When calculating the recharge of groundwater, tracer (Cl) is mainly input by atmospheric precipitation and dry deposition in the natural state. In contrast, the input of the irrigation water should be considered under irrigation conditions. The chloride mass balance (CMB) method can estimate the groundwater recharge rate in arid and semi-arid areas. Therefore, the CMB method is used to estimate the recharge of groundwater by irrigation water and precipitation. With the strong mobility of chlorine along the flow path, it can trace and analyze the chemical and pollutant input of infiltration to groundwater.

The unique isotopic composition of different water bodies is widely used to determine the various components in groundwater systems. Generally, water maintains its stable isotope characteristics without being diluted and mixed with other water sources. The stable isotopic composition can identify the recharge area of groundwater and water circulation in groundwater systems, which have been successfully used in arid and semi-arid regions (Payne,1978; Weyhenmeyer, 2002; Currell,2105). Since the 1980s, many sampling campaigns have been conducted in the North China Plain to study the chemistry and isotopes of groundwater system (Zhang, 1987; Chen, 2003(a); Rohden, 2010; Yuan, 2012; Zhai, 2013; Wang, 2017; Qin, 2017). The research mainly collected groundwater, rivers, soil, and precipitation in a short period (Yuan, 2012; Qin, 2017).

The current research has several limitations. The important reference line, the local meteoric water line (LMWL), generally comes from the isotope fitting of local precipitation samples. The conversion of precipitation to different water bodies can be analyzed according to the relative positions of different water bodies and LMWL. The average value of precipitation isotope 
can be used to calculate the mixing ratio of different water end members in the groundwater system. Therefore, the study has two problems. One is that the precipitation collection campaigns are intermittent, and the accuracy of LMWL is limited by the number of samples and sampling time. The other is that the arithmetic mean in the end-member mixing calculation is likely to increase the uncertainty because of the prominent isotopic dispersive characteristics of precipitation (Zhai, 2013). Previous studies have shown that the isotopes of deep groundwater are far more depleted than local precipitation. It is suggested that the depleted groundwater is recharged by precipitation in the late Pleistocene (Chen, 2003(a)). Jasechko (2016) interpolated the global $\delta^{18} \mathrm{O}$ value in the late Pleistocene with the difference of late-Pleistocene minus late-Holocene precipitation $\delta^{18} \mathrm{O}$ less than $-6 \%$ in the global and $-1--2 \%$ in the North China Plain. However, the $\delta^{18} \mathrm{O}$ value of groundwater collected in the North China Plain (Hengshui) is $-3.4 \%$ o lower than Holocene precipitation, with the range exceeding precipitation in the late Pleistocene. The groundwater recharged by precipitation in the late Pleistocene is fossil water with no renewal capacity. Contradictorily, the latest study found that the groundwater level declined because of groundwater exploitation during the irrigation period and steadily rose during the non-irrigation period (Long, 2020). It shows that groundwater is rapidly recharged by modern water. The depleted groundwater has two contradictory conclusions. Thus, the transformation process and the sources of depleted groundwater need further research.

Based on the sediment samples in the unsaturated zone, water chemistry and stable isotopes are used to (1) estimate the groundwater recharge from precipitation and irrigation calculated by the $\mathrm{CMB},(2)$ analyze the transformation process of precipitation-soil water-groundwater, and (3) understand the impact of solute and pollutants dissolved by infiltration on groundwater quality. This study contributes to the sustainable development of groundwater and the control of agricultural pollution in groundwater in the North China Plain.

\section{Materials And Methods}

\subsection{Study area}

The North China Plain $\left(32^{\circ} \sim 40^{\circ} \mathrm{N}, 114^{\circ} \sim 121^{\circ} \mathrm{E}\right)$ is a semi-arid and semi-humid area dominated by monsoons. The annual average precipitation of Shijiazhuang Station from 1985 to 2003 was 554 mm (IAEA: https://www.iaea.org ), of which summer precipitation (June-August) accounted for approximately $63 \%$ of the total annual precipitation. The annual average temperature is $14^{\circ} \mathrm{C}$, and the potential evaporation within the year is $1100-2000 \mathrm{~mm}$.

The land-use types of the North China Plain are mainly farmland and woodland. The woodland includes coniferous forest, broad-leaved forest, and shrubland. The farmland is primarily wheat, corn, vegetables, and cotton (Min, 2018). Given that the distribution of precipitation during the year is inconsistent with the water demand period of crops, irrigation is used to meet the water demand for crop growth. Agricultural irrigation water mainly comes from the extraction of groundwater. The average annual irrigation water for winter wheat and summer maize is $317 \mathrm{~mm}(\mathrm{Hu}, 2016)$.

The North China Plain is an alluvial plain formed by sedimentation carried by rivers, such as the Yellow River, the Haihe River, and the Luan River. The distribution of the soil texture of the plain is related to the source of the sediment. Loam, loamy sand, and clay account for $90 \%$ of the plain area. The North China Plain is divided into piedmont plains (I), central plains (II), and coastal plains (III) from west to east (Fig. 1). The groundwater level of the piedmont plain is generally between 10 and $40 \mathrm{~m}$, and the unsaturated zone is mainly silt and fine sand. The groundwater depth of the central plain is 1-20 m, and the unsaturated zone is mainly divided into clay and silt. The groundwater depth in the coastal plain is generally between 1 and 4 $\mathrm{m}$, and the unsaturated zone is mostly clay.

\subsection{Sampling and laboratory analyses}

Four soil profiles were collected in a typical irrigation area in May 2018 to consider the influence of irrigation water on infiltration (Fig. 1). Each time after sampling soil, the cores were filled tightly. Bulk soil samples of approximately $250 \mathrm{~g}$ were collected at intervals of $10 \mathrm{~cm}$ in shallow soil $(<20 \mathrm{~cm})$ and $20 \mathrm{~cm}$ in deep soil $(>20 \mathrm{~cm})$ for stable isotope analysis. Samples 
were immediately sealed in airtight polyethylene bottles to prevent evaporation or atmospheric moisture pollution in the field. Groundwater samples were also performed from nearby drinking wells at the same time.

Soil moisture content is analyzed with the oven drying method with an analytical precision of better than $1 \%$. To measure $\mathrm{Cl}^{-}$ concentration in soil water, the soil sample was dried at $110{ }^{\circ} \mathrm{C}$ for $12 \mathrm{~h}$, and then $50 \mathrm{~g}$ of the dried soil was mixed with 100 $\mathrm{ml}$ of deionized water. The mixture was allowed to equilibrate for $48 \mathrm{~h}$ and periodically stirred (Scanlon, 2009). After equilibration, the leachate was filtered with medium-speed quantitative filter paper for anions measurement. Solutes and groundwater samples were then analyzed by ion chromatography. Then the anions ( $\mathrm{Cl}$-) concentrations in soil water were converted according to soil moisture content.

Water for stable isotope analyses was extracted from the bulk soil samples using azeotropic distillation at $105^{\circ} \mathrm{C}$. For stable isotope composition analysis of the extracted water samples, the water was directly introduced into a Flash EA sample injection system attached via a micro-pump to a Mat 253 mass spectrometer. All measurements were performed at the State Key Laboratory of Hydrology Water Resources and Hydraulic Engineering, Hohai University, China. The results are reported relative to $\mathrm{V}$-SMOW, with uncertainties of $\pm 1 \%$ in $\delta^{2} \mathrm{H}$ and $\pm 0.20 \%$ in $\delta^{18} \mathrm{O}$.

\subsection{Data Analysis}

Chloride hardly participates in geochemical processes in the hydrological cycle. It is a stable environmental tracer and has a strong ability to migrate with water. Thus, it is used to estimate the average groundwater recharge. Groundwater recharge rates were calculated using the CMB method (Eq. (1)). The assumptions of the CMB method (Allison, 1978; Min, 2018) are as follows: (1) The sources of chloride are precipitation and irrigation water in an agricultural area; (2) lateral flow and surface runoff are negligible, and infiltration is the one-dimensional downward vertical water flow; and (3) chloride transport reaches a steady state.

Based on the above assumptions, the chloride input from precipitation ( $\mathrm{P}, \mathrm{mm} / \mathrm{yr})$ and irrigation $(\mathrm{l}, \mathrm{mm} / \mathrm{yr})$ balances the chloride output in the recharge $(\mathrm{R}, \mathrm{mm} / \mathrm{yr})$ as follows:

$\mathrm{P} \times \mathrm{Cl}_{P}+I \times \mathrm{Cl}_{I}=\mathrm{R} \times \mathrm{Cl}_{\mathrm{s}}$

Where $\mathrm{Cl}_{\mathrm{P}}(\mathrm{mg} / \mathrm{L})$ and $\mathrm{Cl}_{\mathrm{I}}(\mathrm{mg} / \mathrm{L})$ are the average chloride concentration in the rainfall and irrigation water, respectively, and $\mathrm{Cl}_{S}(\mathrm{mg} / \mathrm{L})$ is the average chloride concentration of the soil water below the root zone. The average precipitation values at Shijiazhuang, Hengshui, and Cangzhou are 534, 497, and $542 \mathrm{~mm}$, respectively. The soil texture of the four profiles (A, B, C, D) is sand, clay, sandy/ clay and sandy, respectively. The bulk density of sand and clay is $1.5 \mathrm{and} 1.3 \mathrm{~g} / \mathrm{cm}^{3}$, respectively.

Records of solute concentrations in rainfall are sparse for much of China. The chloride concentration of precipitation in Shijiazhuang varies from $1.8 \mathrm{mg} / \mathrm{L}$ to $2.9 \mathrm{mg} / \mathrm{L}$ according to the acid rainfall monitoring data (Hong, 2014). The monthly weighted mean chloride concentration of precipitation in Cangzhou is from the rainfall sample from April to November in 2009 (Wang, 2014). The summer oceanic monsoon mainly influences precipitation in the study area, and the concentration is strongly controlled by the distance to its oceanic source. Hengshui is midway between the monsoon paths of Cangzhou and Shijiazhuang. Therefore, the chloride concentration of precipitation in Hengshui can be replaced by the average value in Shijiazhuang and Cangzhou.

Winter wheat and summer corn were planted by rotation in the North China Plain. Irrigation water was the sum of irrigation of winter wheat (320 mm/yr) and summer corn (50 mm/yr) (Min, 2018). The agricultural irrigation water consumption in Shijiazhuang $(A)$ and Hengshui $(B, C)$ is derived from the deep groundwater extracted. The chloride concentration of irrigation water can be represented by that of nearby groundwater. Furthermore, given the overexploitation of groundwater, extracted deep groundwater in Cangzhou (D) is only used for drinking water, and agricultural water is mainly from reservoirs. The concentration of samples in Huangbizhuang reservoir is used in calculation collected in 2012. The depth of root affected 
area is mainly controlled by root depth and plant evapotranspiration. The vegetation coverage in sites A, B, C, and D was winter wheat, and the root influence depth was generally 1-1.5 m (Min, 2018).

\section{Results}

\subsection{Groundwater recharge estimated by $\mathrm{CMB}$}

The calculation of CMB shows that the average groundwater recharge at sites A, B, C, and D is $66,95,144$, and $307 \mathrm{~mm} / \mathrm{yr}$ (Table 1), accounting for $7 \%, 11 \%, 17 \%$, and $34 \%$ of precipitation and irrigation water, respectively. The chloride concentration of groundwater $(115.9 \mathrm{mg} / \mathrm{L})$ near site $D$ is much higher than that of soil water $(38.5 \mathrm{mg} / \mathrm{L})$, and the background value of chloride in the stratum is high. Therefore, the premise of the chloride source is broken, and the calculation results are not credible. The calculated recharge indicates that the recharge of precipitation and irrigation to groundwater is limited. The change of irrigation water has little effect on groundwater recharge in the agricultural area of North China Plain. The vegetation coverage conditions of the four sites are the same. Still, the average groundwater recharge is significantly different, which may be related to the source of irrigation water and soil texture because various irrigation water sources input different chloride concentrations.

Table 1

Site descriptions, chloride concentration in precipitation and recharge rate in four sites

\begin{tabular}{|c|c|c|c|c|c|c|c|c|c|c|}
\hline $\begin{array}{l}\text { Setting } \\
\text { borehole }\end{array}$ & Location & $\begin{array}{l}\text { Land } \\
\text { use }\end{array}$ & $\begin{array}{l}\text { Maximum } \\
\text { depth (m) }\end{array}$ & $\begin{array}{l}\begin{array}{l}\text { Bulk } \\
\text { density }\end{array} \\
\left(\mathrm{g} / \mathrm{m}^{3}\right)\end{array}$ & $\begin{array}{l}P_{a} \\
(m m)\end{array}$ & $\begin{array}{l}\mathrm{I}_{\mathrm{a}} \\
(\mathrm{mm})\end{array}$ & $\begin{array}{l}{[\mathrm{Cl}]_{\mathrm{P}}} \\
(\mathrm{mg} / \mathrm{L})\end{array}$ & $\begin{array}{l}{[\mathrm{Cl}]_{\mathrm{I}}} \\
(\mathrm{mg} / \mathrm{L})\end{array}$ & $\begin{array}{l}\text { Depth } \\
\text { (m) }\end{array}$ & $\begin{array}{l}\text { R } \\
(\mathrm{mm} / \mathrm{yr})\end{array}$ \\
\hline A & Shijiazhuang & Wheat & 4 & 1.5 & 534 & 370 & 2.5 & 20.7 & 1.6 & 66 \\
\hline B & Hengshui & Wheat & 4 & 1.3 & 497 & 370 & 1.9 & 84.1 & 1.4 & 95 \\
\hline C & Hengshui & Wheat & 4 & $1.5^{\star} / 1.3^{\star}$ & 497 & 370 & 1.9 & 84.1 & 1.6 & 144 \\
\hline D & Cangzhou & Wheat & 5 & 1.5 & 542 & 370 & 1.4 & 27.3 & 1.6 & 307 \\
\hline
\end{tabular}

Given that the chloride concentration data of precipitation and irrigation are only available for a few years or months, longterm monitoring data is lacking. The inaccuracy of chloride concentration of precipitation and irrigation increases the uncertainty of the calculated average groundwater recharge. The source of chloride ignores the input of atmospheric dry deposition, which may reduce the calculated value.

\subsection{Isotopic characteristics}

\subsubsection{Hydrogen and oxygen isotope composition in precipitation}

Stable isotope data of precipitation at Shijiazhuang station were downloaded from GNIP (IAEA: https://www.iaea.org ). Figure 2(a) shows that the ${ }^{18} \mathrm{O}$ and ${ }^{2} \mathrm{H}$ values of precipitation range from $-16.0 \%$ o to $-0.3 \%$ and -111.3 to $0.7 \%$, and the average values are $-7.6 \%$ and $-51.9 \%$, respectively. The weighted average of ${ }^{18} \mathrm{O}$ and ${ }^{2} \mathrm{H}$ is $-7.3 \%$ ond $-51.9 \%$, respectively. Local Meteoric Water Line (LMWL: $\delta^{2} \mathrm{H}=6.07 \delta^{18} \mathrm{O}-5.76, \mathrm{R} 2=0.86$ ) is obtained by fitting precipitation points. The slope and intercept of LWML are affected by the local climate, and thus are slightly different from Global Meteoric Water Line (GWML: $\delta^{2} \mathrm{H}=8 \delta^{18} \mathrm{O}+10$ ) (Graig,1961). Compared with GWML, the lower slope of LWML may be related to the secondary evaporation of precipitation. The study area is located in a semi-arid area with strong evaporation. After the water vapor 
condenses, the secondary evaporation of precipitation may occur when it descends through dry air. Secondary evaporation significantly reduces the value of excess deuterium. Excess-d is defined as follows: excess- $d=\delta^{2} \mathrm{H}-8 \delta^{18} \mathrm{O}$. The average value of excess-d of rainfall is $6 \%$, which is less than the average value of GWML (10\%o).

In the region, the stable isotope characteristics of precipitation are mainly affected by the effects of latitude, elevation, temperature, and precipitation. Temperature controls the isotope fractionation processes in evaporation and condensation, generally resulting in the enrichment of isotopes in summer and depletion of isotopes in winter (Clark, 1997). The ${ }^{18} \mathrm{O}$ and ${ }^{2} \mathrm{H}$ of precipitation change significantly, with maximum values reaching $-3.7 \%$ ond $-27.5 \%$, and minimum values being $11.4 \%$ and $-78.8 \%$, respectively (Fig. 2(b)), showing obvious dispersion during the year. From October to April, the changes of ${ }^{18} \mathrm{O}$ and ${ }^{2} \mathrm{H}$ in precipitation are positively correlated with temperature (Fig. 2(c)). As the temperature decreases, the isotopes deplete, which is consistent with the characteristics of the temperature effect. From May to September, the changes

of ${ }^{18} \mathrm{O}$ and ${ }^{2} \mathrm{H}$ are affected by rainfall, which causes the isotope value to decrease with the increase of rainfall. Therefore, the isotopic characteristics of precipitation are simultaneously affected by temperature and precipitation, and the most enriched isotopes do not appear in summer and winter, except in April.

\subsubsection{Hydrogen and oxygen isotope composition in soil water and groundwater}

The vertical distribution of $\delta^{2} \mathrm{H}$ and $\delta^{18} \mathrm{O}$ of soil water in sites $\mathrm{A}, \mathrm{B}, \mathrm{C}$, and $\mathrm{D}$ is shown in Fig. 3 . As the depth increases, stable isotopes are gradually depleted with slight fluctuations. The fluctuation may be related to the evaporation and condensation of water vapor in the soil. The $\delta^{2} \mathrm{H}$ and $\delta^{18} \mathrm{O}$ in the topsoil $(0-20 \mathrm{~cm})$ are significantly enriched, and the variation ranges are $8.8 \% o^{-}-60.2 \%$ and $-1.2--7.3 \%$ o (Fig. 3), indicating that the topsoil is strongly affected by evaporation. Below $20 \mathrm{~cm}$, the average values of $\delta^{2} \mathrm{H}$ and $\delta^{18} \mathrm{O}$ at locations $\mathrm{A}, \mathrm{B}, \mathrm{C}$, and $\mathrm{D}$ are $-69.9 \%$ and $-8.8 \%$ o, $-65.2 \%$ and $-8.6 \%$, $-69.2 \%$ and $9.1 \%$ o, $-73.4 \%$ ond $-9.9 \%$, respectively. The effect of evaporation is reduced. The soil texture at sites $A$ and $D$ is sandy. The isotopic characteristics of the deep soil water and nearby groundwater indicate that the groundwater replenishes the deep soil from bottom to top through the capillary in the sand. The soil texture at sites B and C is clay. The isotope of the deep soil water is significantly enriched compared with that of the nearby groundwater, indicating that soil seepage water accounts for little proportion of depleted groundwater.

In Fig. 4, the soil water evaporation line (SWL: $\left.\delta^{2} \mathrm{H}=6.55^{\star} \delta^{18} \mathrm{O}-9.67, \mathrm{R} 2=0.94\right)$ is fitted by the points of soil water. The lower slope of SWL compared with GMWL and the points of soil water below GMWL, indicating that soil water is significantly affected by evaporation. The intersection values of SWL and GMWL are $-98.8 \%$ ond $-13.6 \%$, which represent the initial value of soil water without evaporation. The initial value is more depleted than the average weighted precipitation by $-6.3 \%$ and $-46.9 \%$, indicating that precipitation is not the source of the initial water of deep soil water before evaporation.

Groundwater and soil water fall within the same range, and groundwater is relatively more depleted. The initial value is close to the groundwater point, indicating that groundwater recharges the deep soil water. The direction of water transmission is from the groundwater to the unsaturated zone.

\subsection{Hydrochemistry in the soil profile}

When precipitation infiltrates through the unsaturated zone to recharge groundwater, solutes in the surface and the unsaturated zone are leached into the groundwater. The water chemistry of the infiltration water should have continuity in the flow path. Therefore, the movement of soluble ions can trace the movement process of the infiltration water.

Figure 5 shows that the average soil moisture content of sites A, B, C, and D is $9.8 \%, 30.0 \%, 26.7 \%$, and $26.2 \%$, respectively. The moisture content varies greatly with depth and has no apparent correlation with the vertical distribution of chloride concentration. The low chloride concentration in the topsoil is related to the dilution of soil water by precipitation. As the depth increases, the chloride concentration of the soil water increases significantly. At sites $A, B, C$, and $D$, the average chloride concentration of soil water is $106.3,232.1,512.7$, and $38.5 \mathrm{mg} / \mathrm{L}$, respectively, and the chloride concentration of nearby groundwater is 20.7, 82.9, 83.3, and $115.9 \mathrm{mg} / \mathrm{L}$, respectively. Except for site $\mathrm{D}$, the chloride concentration of soil water 
is much higher than that of groundwater, and the hydrochemical characteristics of soil water and groundwater are not continuous, indicating that precipitation cannot infiltrate to recharge groundwater through the unsaturated zone. The high concentration of chloride has not yet penetrated the groundwater and caused groundwater pollution. The chloride concentration of groundwater should be equivalent to the concentration of deep soil water.

The chloride concentration of groundwater is much higher than that of soil water at site D. The high concentration of chloride of groundwater may be related to the dissolution of evaporates in the stratum in coastal areas rather than the recharge of soil water with low chloride concentration. At site $\mathrm{C}$, the chloride concentration of the soil water increases significantly at a depth of 1.0-1.2 m. This increase is caused by reduced permeability because of soil texture changing from sandy to clay. Infiltration water in this layer is intercepted, and chloride is accumulated after the water evaporates.

\section{Discussion}

\subsection{Transformation process of precipitation-soil water-groundwater}

Affected by temperature and precipitation, the ${ }^{18} \mathrm{O}$ and ${ }^{2} \mathrm{H}$ of the precipitation in the study area show evident dispersion during the year. Research in Beijing has found that the dispersion of stable isotopes occurs annually and interannually (Zhai, 2013). This dispersive characteristic has also been observed in Hong Kong and Guangzhou (Zhang, 2009; Xie, 2011). Although the reason and mechanism of this phenomenon are not apparent, isotope values of single or seasonal precipitation cannot be used to analyze the evolution process and calculate groundwater recharge and end-member mixing. The weighted average of precipitation over a long time series should be used to eliminate the dispersive characteristics and the influence of precipitation. Based on the monitoring data of precipitation isotopes from 1985 to 2003 , the average weighted precipitation calculated is $-7.3 \%$ and $-51.9 \%$, which is not significantly different from the arithmetic mean $(-7.6 \%$ and $-51.9 \%$ ). However, it eliminates the influence of dispersion and precipitation and is more reasonable in physics.

In arid or semi-arid regions, the isotopes of topsoil water are significantly enriched by evapotranspiration. With the occurrence of subsequent precipitation events, the enriched isotopes move downward with the infiltration. A recharge rate up to 200 $\mathrm{mm} / \mathrm{yr}$ generally causes periodic changes of isotopes in the vertical. Preferential flow can make the enriched soil water flow down quickly, forming other peaks of stable isotopes in the soil profile. The stable isotopes of the four soil profiles in this study only have a peak in the topsoil. The isotope is enriched, and the isotope is gradually depleted with the increase of depth, showing that the seepage mode in the soil profile is mainly piston flow instead of preferential flow, which satisfies the assumption of piston flow in the CMB method. No periodic change is observed in the isotope, indicating that the lower recharge causes the peak and trough to be close. The subsequent diffusion smoothens the difference between the peak and trough. Thus, the periodicity disappeared. Site D is located in Cangzhou in the coastal plain. The chloride background value in the aquifer is up to $115.9 \mathrm{mg} / \mathrm{L}$, which may be related to the seawater intrusion in the geological history period. Therefore, it breaks the assumption that the source of chloride is only from precipitation and irrigation, and the CMB method is not applicable in this area.

Isotope analysis found that the initial value of deep soil water before evaporation fell within the range of groundwater, indicating the recharge from groundwater to deep soil water. Groundwater is significantly more depleted than local atmospheric precipitation, meaning that precipitation accounts for a small proportion of groundwater recharge. In the groundwater system, no water-rock interaction causes the groundwater to evolve toward depletion. The depleted groundwater was recharged by precipitation in the cold late Pleistocene (Chen, 2003(a)). Jasechko (2016) interpolated the global $\delta^{18} \mathrm{O}$ value in the late Pleistocene with the difference of late-Pleistocene minus late-Holocene precipitation $\delta^{18} \mathrm{O}$ less than $-6 \%$ globally and $-1--2 \%$ in the North China Plain. However, the $\delta^{18} \mathrm{O}$ value of groundwater collected in the North China Plain (Hengshui) is $-3.4 \%$ o lower than Holocene precipitation with a range exceeding precipitation in the late Pleistocene. The groundwater recharged by precipitation in the late Pleistocene is fossil water with no renewal capacity. Contradictorily, the latest study found that the groundwater level declined because of groundwater exploitation during the irrigation period and 
steadily rose during the non-irrigation period (Long, 2020). Therefore, modern water can quickly recharge groundwater. The isotopes of precipitation significantly are reduced by the altitude effect; thus, groundwater may be recharged by leakage water from high altitude areas.

\subsection{Mechanisms of Increasing Recharge Related to Irrigation}

From 2000 to 2018, the average agricultural area in the North China Plain is 9.27×103 ha (National Bureau of Statistics: http://data.stats.gov.cn ). The crops are mainly wheat, corn, cotton, and vegetables, and wheat and corn account for more than $60 \%$. Therefore, the literature on the groundwater recharge for wheat and corn in irrigated areas is compiled. Groundwater recharge in literature is shown in Table 2. Although different methods estimate differences in groundwater recharge, the recharge in irrigated areas is significantly higher than that in non-irrigated areas as a whole.

Table 2

Groundwater Recharge calculated by different methods in North China Plain

\begin{tabular}{|c|c|c|c|c|}
\hline Input type & Location & $\mathrm{R}(\mathrm{mm} / \mathrm{yr})$ & Method & Reference \\
\hline \multirow[t]{11}{*}{ With Irrigation } & Piedmont Plain & $169-180$ & Hydrus-1D & Lu,2011 \\
\hline & & $36-209$ & One-dimensional soil-water-balance model & Kendy,2003 \\
\hline & & 38 & Water balance and ${ }^{3} \mathrm{H}$ tracers & Chen,2003 \\
\hline & & 300 & ${ }^{3} \mathrm{H}-{ }^{3} \mathrm{He}$ tracers and water balance & Rohden,2010 \\
\hline & & 78 & CMB (Chloride mass balance) & This paper \\
\hline & Central Plain & $140-155$ & Hydrus-1D & Lu,2011 \\
\hline & & $102-158$ & CMB (Chloride mass balance) & This paper \\
\hline & Coastal Plain & 102 & Hydrus-1D & Lu,2011 \\
\hline & & $153-211$ & Tritium and Bromide tracers & Wang,2008 \\
\hline & & $50-1090$ & Soil-water balance & Kendy,2004 \\
\hline & & 233 & transient matric flow model & Min,2015 \\
\hline Without Irrigation & Piedmont Plain & 3.8 & CMB (Chloride mass balance) & Yuan,2012 \\
\hline
\end{tabular}

The soil water balance equation in the unsaturated zone is as follows:

$\mathrm{R}=\mathrm{T}-\mathrm{ET}-R_{0}$

where $\mathrm{R}$ is the average groundwater recharge; $\mathrm{T}$ is the total amount of input water, including precipitation and irrigation; $\mathrm{ET}$ is evapotranspiration; and $\mathrm{R}_{0}$ is surface runoff. Compared with non-irrigated areas, the higher groundwater recharge in irrigated areas is related to increased water input and decreased evapotranspiration. The water input of the irrigation area includes precipitation and irrigation, and the irrigation is the short-duration and high-intensity pulse input. The deep leakage below the root zone in the irrigation area is significantly higher than that in the non-irrigated area, thus increasing groundwater recharge in the irrigated area. Given the centralized groundwater extraction to meet irrigation needs, the groundwater level drops and surface evapotranspiration reduces (Condon, 2019).

The higher groundwater recharge in the irrigated area is also related to the root depth of the vegetation. The vegetation in the non-irrigated area is mainly woods, which are perennial plants with a developed root system. After a heavy rainfall event, deep seepage occurs, and soil moisture is redistributed. The root of perennial vegetation can absorb and reuse the deep leakage water, which is consistent with the monitoring results of the matric potential in the unsaturated zone that the matrix 
potential changes little with a depth greater than $5 \mathrm{~m}$ (Scanlon, 2007). The crops in the irrigation area are mostly annual plants, the root depth of which is only approximately $1.5 \mathrm{~m}$, such as wheat, corn, and cotton (Min, 2018). After heavy rainfall or irrigation, deep seepage occurs, the root system only absorbs seepage water in the topsoil, and the deep seepage water is easily recharged to the groundwater. Therefore, the depth of the root system causes the difference in groundwater recharge between irrigated and non-irrigated areas. The type of irrigation is mainly flood irrigation in the North China Plain, which is a short-duration and high-intensity water input. The infiltration mechanism is similar to that of a heavy rainfall event. Deep seepage water is more likely to reach and recharge shallow groundwater.

\subsection{Influence of infiltration on groundwater quality}

Precipitation infiltrates to leach solutes in the unsaturated zone and recharges groundwater. Therefore, solute and contaminants transport in the unsaturated zone is crucial for groundwater quality. The analysis in Sect. 3.3 shows a significant accumulation of chloride in the unsaturated zone. In the agricultural areas of the North China Plain, fertilizers and pesticides are widely used to increase crop yields. The infiltration of precipitation and irrigation can leach the $\mathrm{NO}_{3}{ }^{-}, \mathrm{SO}_{4}{ }^{2-}$, and contaminants produced by agriculture into the unsaturated zone. Affected by plant root absorption or microbial activity, $\mathrm{NO}_{3}{ }^{-}$and $\mathrm{SO}_{4}{ }^{2}$ concentration in the shallow root zone decreases. With less influence of microbial activity in deep soils, $\mathrm{NO}_{3}{ }^{-}$ and $\mathrm{SO}_{4}{ }^{2-}$ are accumulated and form solute accumulation zones with a high concentration of pollutants (Min,2018). When the infiltration water seeps downward, a high concentration of soluble irons and pollutants can be leached into the shallow groundwater (Taylor,2013), which seriously pollutes the groundwater.

In the North China Plain, the solute in the unsaturated zone comes from agriculture and salt accumulation during the salinealkali period in history. Before the 1960s, groundwater extraction was less than $2 \times 10^{8} \mathrm{~m}^{3} / \mathrm{a}$ in the North China Plain, and the groundwater level was close to or higher than the surface. The high groundwater level supports capillary water to rise to reach the strong evaporation layer. The moisture in the strongly evaporation layer is evaporated into the atmosphere, and the capillary quickly transports the water upward. As water evaporates, salt remains in the topsoil and forms a high-salt accumulation layer (Fig. 6) (i.e., soil salinization). After the 1960s, groundwater was intensively extracted to meet water demand, and the groundwater level continued to drop. Until the 1980s, salinization gradually disappeared as the water level dropped. The solute accumulation zone shows that the salt accumulated in the topsoil was leached by infiltration and stored in the unsaturated zone.

High concentrations of solutes and contaminations were found in the unsaturated zone. When precipitation and irrigation infiltrate the unsaturated zone, the solutes and contaminations are dissolved and carried into the shallow groundwater. Therefore, the infiltration depth seriously affects the quality of groundwater. For example, in the high permeability area of Hengshui, precipitation and irrigation water seep fast, resulting in the TDS of shallow groundwater was monitored to be as high as $9 \mathrm{~g} / \mathrm{L}$ (Shi, 2010). The recharge of groundwater by infiltration is affected by groundwater level and the intensity of rainfall and irrigation. To minimize the impact of agricultural pollution on groundwater quality, controlling the groundwater level and the intensity of single irrigation is recommended to reduce the effect of precipitation and irrigation water on groundwater.

\section{Conclusion}

The hydrogen and oxygen isotopes of deep soil water slightly vary vertically with no periodic variation. The infiltration mode is dominated by piston flow in the unsaturated zone, which meets the premise hypothesis of the chlorine mass balance method. Based on the CMB method, the average groundwater recharge in irrigation areas of Hengshui and Shijiazhuang is $66-95 \mathrm{~mm} / \mathrm{yr}$ and $144 \mathrm{~mm} / \mathrm{yr}$, respectively, accounting for $7-11 \%$ and $17 \%$ of precipitation and irrigation water, respectively. The background value of chloride in the stratum is as high as $115.9 \mathrm{mg} / \mathrm{L}$ in Cangzhou, which breaks the assumption that the source of chloride is only from precipitation and irrigation. Therefore, the calculation results are unreliable, and the CMB method is unsuitable for coastal plains. 
The analysis of the stable isotopes of precipitation, groundwater, and soil water revealed that the soil water in topsoil is enriched because of the strong influence of evaporation. The initial value is much more depleted than the average weighted precipitation, indicating that precipitation only affects soil water in the topsoil, and deep soil water is mainly recharged upward by groundwater. The depleted groundwater with characteristics of modern water monitored in previous studies may be related to leakage water in high-altitude areas.

Contaminations and solute are accumulated in the unsaturated zone, which are mainly from agriculture and salinization. When precipitation and irrigation infiltrate through the unsaturated zone, the solutes and pollutants are leached and brought into the shallow groundwater, causing shallow groundwater pollution. Given the short-duration and high-intensity pulse input of irrigation, groundwater pollution is more likely to occur in the irrigation area. Therefore, the groundwater level and single irrigation intensity should be controlled to reduce the recharge of precipitation and irrigation to groundwater, which is vital for groundwater quality protection.

\section{Declarations}

\section{Ethics approval and consent to participate}

Not applicable.

\section{Consent for publication}

Not applicable.

\section{Availability of data and materials}

Stable isotope data of precipitation is applicable at GNIP network (IAEA: https://www.iaea.org ).

\section{Conflicts of interest/Competing interests}

The authors have no conflicts of interest to declare that are relevant to the content of this article.

\section{Acknowledgments}

This work was funded by the Fundamental Research Funds for the Central Universities (No: 2018B48814). The authors are grateful for the help of the State Key Laboratory of Hydrology-Water Resources and Hydraulic Engineering at Hohai University, where all analyses were performed.

\section{Authors' contributions}

Conceptualization: [Jiansheng Chen]; Methodology: [Xi Zhang]; Formal analysis and investigation: [Xi Zhang], [Lucheng Zhan], [Fenyan Ma], [Jiaheng Yan]; Writing-original draft preparation: [Xi Zhang]; Writing-review and editing: [Tao Wang], [Lucheng Zhan]; Funding acquisition: [the Fundamental Research Funds for the Central Universities (No: 2018B48814)]; Supervision: [Jiansheng Chen].

\section{References}

1. Allison G B , Hughes M W (1978). The use of environmental chloride and tritium to estimate total recharge to an unconfined aquifer. Soil Research, 16.https://doi.org/10.1071/sr9780181

2. Guoliang, Cao, Bridget, et al (2016). Impacts of thickening unsaturated zone on groundwater recharge in the North China Plain. Journal of Hydrology, 537(537):260-270.https://doi.org/10.1016/j.jhydrol.2016.03.049

3. Chen Z , Qi J , Xu J , et al (2003). Paleoclimatic interpretation of the past 30 ka from isotopic studies of the deep confined aquifer of the North China plain. Applied Geochemistry, 18(7):997-1009. (a)https://doi.org/10.1016/S0883- 
2927(02)00206-8

4. Chen J Y , Tang C Y , Shen Y J , et al (2003). Use of water balance calculation and tritium to examine the dropdown of groundwater table in the piedmont of the North China Plain (NCP). Environmental Geology, 44(5):564-571.

(b)https://doi.org/10.1007/s00254-003-0792-3

5. Clark, I. D., \& Fritz, P. (1997). Environmental isotopes in hydrogeology. Boca Raton: Lewis.

6. Condon L E, Maxwell R M (2019). Simulating the sensitivity of evapotranspiration and streamflow to large-scale groundwater depletion. Science Advances, 5(6):eaav4574.https://doi.org/10.1126/sciadv.aav4574

7. Currell M J ,Dahlhaus P, li H (2015). Stable isotopes as indicators of water and salinity sources in a southeast Australian coastal wetland: identifying relict marine water, and implications for future change. Hydrogeology Journal, 23(2):235248.https://doi.org/10.1007/s10040-014-1199-9

8. Craig H (1961). Isotopic variations in meteoric waters. Science.https://doi.org/10.1126/science.133.3465.1702

9. Healy R W, Cook P G (2002). Using groundwater levels to estimate recharge. Hydrogeology Journal,10(1): 91109.https://doi.org/10.1007/s10040-001-0178-0

10. Hong G , Zhou J , Lan Y , et al (2014). Characteristics and cause analysis on acid rain pollution in Shijiangzhuang City. Heibei Journal of Industrial Science and Technology, 31(6):547-551.

11. Hu X, Shi $L$, Zeng J , et al (2016). Estimation of actual irrigation amount and its impact on groundwater depletion: $A$ case study in the Hebei Plain, China. Journal of Hydrology, 543:433-449.https://doi.org/10.1016/j.jhydrol.2016.10.020

12. Jasechko, S (2016). Late-Pleistocene precipitation $\delta^{18} \mathrm{O}$ interpolated across the global landmass. Geochemistry Geophysics Geosystems, 17.https://doi.org/10.1002/2016GC006400

13. Long D , Yang W , Scanlon B R, et al (2020). South-to-North Water Diversion stabilizing Beijing's groundwater levels. Nature Communications, 11(1).https://doi.org/10.1038/s41467-020-17428-6

14. Kendy E, P Gérard-Marchant, Walter M T , et al (2003). A soil-water-balance approach to quantify groundwater recharge from irrigated cropland in the North China Plain. Hydrological Processes, 17(10): 2011-

2031.https://doi.org/10.1002/hyp.1240

15. Kendy E, Zhang Y, Liu C , et al (2004). Groundwater recharge from irrigated cropland in the North China Plain: case study of Luancheng County, Hebei Province, 1949-2000. Hydrological Processes,18(12): 2289-

2302.https://doi.org/10.1002/hyp.5529

16. Lu X , Jin M , Genuchten M , et al (2011). Groundwater recharge at five representative sites in the Hebei Plain, China. Ground Water, 49(2): 286-94. https://doi.org/10.1111/j.1745-6584.2009.00667.x

17. Min L , Shen Y , Pei H (2015). Estimating groundwater recharge using deep vadose zone data under typical irrigated cropland in the piedmont region of the North China Plain. Journal of Hydrology, 527:305-315. https://doi.org/10.1016/j.jhydrol.2015.04.064

18. Min L , Shen Y , Pei H , et al (2018). Water movement and solute transport in deep vadose zone under four irrigated agricultural land-use types in the North China Plain. Journal of Hydrology, 559:510-522. https://doi.org/10.1016/j.jhydrol.2018.02.037

19. Payne B R ,Leontiadis J , C D imitroulas, et al (1978). A study of the Kalamos Springs in Greece with environmental isotopes. Water Resources Research, 14(4):653-658. https://doi.org/10.1029/WR014i004p00653

20. Qin D , Zhao Z , Guo Y , et al (2017). Using hydrochemical, stable isotope, and river water recharge data to identify groundwater flow paths in a deeply buried karst system. Hydrological Processes, 2017, 31(24):4297-4314. https://doi.org/10.1002/hyp.11356

21. Scanlon, B.R., R.C. Reedy and J.A. Tachovsky (2007). Semiarid unsaturated zone chloride profiles: Archives of past land use change impacts on water resources in the southern High Plains, United States. Water Resources Research, 43(6). (a)https://doi.org/10.1029/2006WR005769 
22. Scanlon, B.R., et al (2009). Inventories and mobilization of unsaturated zone sulfate, fluoride, and chloride related to land use change in semiarid regions, southwestern United States and Australia. Water Resources Research, 45(7):641-648. (b) https://doi.org/10.1029/2008WR006963

23. Shi Y X, Wang G L, Gao Y X (2010). Indication of hydrochemistry and isotope for vertical circulation of groundwater in the North China Plain. Hydrogeology凶Engineering Geology, 37(04):18-23. https://doi.org/10.1016/S1876-3804(11)600049

24. Taylor R G, Scanlon B R, Doll P, et al (2013). Ground water and climate change. Nature Climate Change, 3(4): $322-$ 329.https://doi.org/10.1038/NCLIMATE1744

25. Tyler S W , Chapman J B , Conrad S H, et al (1996). Soil-water flux in the southern Great Basin, United States: temporal and spatial variations over the last 120,000 years. Water Resources Research,32(6): 14811499.https://doi.org/10.1029/96WR00564

26. Rohden C V ,Kreuzer A, Chen Z, et al (2010). Characterizing the recharge regime of the strongly exploited aquifers of the North China Plain by environmental tracers. Water Resources Research, 46(5).https://doi.org/10.1029/2008WR007660

27. Wang B G , Jin M G , Wang W F , et al (2006).Application of Chloride lon Tracer Method in Estimation of Vertical Infiltration Recharge of Groundwater in Hebei Plain. Water Saving Irrigation, (03):16-20.

28. Wang B , Jin M , Nimmo J R, et al (2008). Estimating groundwater recharge in Hebei Plain, China under varying land use practices using tritium and bromide tracers. Journal of Hydrology, 356(1-2):209-

222.https://doi.org/10.1016/j.jhydrol.2008.04.011

29. Wang J., Xu M , Ye X, et al (2014). Analysis on chemical characteristics of atmospheric precipitation in Cangzhou city. Environmental Science区Technology, 37(4): 96-102. https://doi.org/CNKI:SUN:FJKS.0.2014-04-021

30. Wang S, Zheng W, CurrellM , et al (2017). Relationship between land-use and sources and fate of nitrate in groundwater in a typical recharge area of the North China Plain. Science of The Total Environment, 609:607620.https://doi.org/10.1016/j.scitotenv.2017.07.176

31. Weyhenmeyer C E, Burns S J , Waber H N , et al (2002). Isotope study of moisture sources, recharge areas, and groundwater flow paths within the eastern Batinah coastal plain, Sultanate of Oman. Water Resources Research, 38(10), 1184-1206.https://doi.org/10.1029/2000WR000149

32. Xie L, Wei G, Deng W , et al (2011). Daily $\delta^{18} O$ and $\delta D$ of precipitations from 2007 to 2009 in Guangzhou, South China: Implications for changes of moisture sources. Journal of Hydrology, 400(3-4):477-

489.https://doi.org/10.1016/j.jhydrol.2011.02.002

33. Yamanaka T , Shimada J , Hamada Y, et al (2004). Hydrogen and oxygen isotopes in precipitation in the northern part of the North China Plain: climatology and inter-storm variability. Hydrological Processes, 18(12):22112222.https://doi.org/10.1002/hyp.5525

34. Yuan, R, Song X, Han D , et al (2012). Rate and historical change of direct recharge from precipitation constrained by unsaturated zone profiles of chloride and oxygen-18 in dry river bed of North China Plain. Hydrological Processes, 26(9):1291-1301.https://doi.org/

35. ZhaiY, Wang J , Zhang Y, et al (2013). Hydrochemical and isotopic investigation of atmospheric precipitation in Beijing, China. Science of The Total Environment, 456-457:202-211.https://doi.org/10.1016/j.scitotenv.2013.03.091

36. Zhang C , Duan Q , PJ-Yeh, et al (2020). The effectiveness of the South-to-North Water Diversion Middle Route Project on water delivery and groundwater recovery in North China Plain. Water Resources Research, 56(10).https://doi.org/10.1029/2019WR026759

37. Zhang L , Chen L , Liu J , et al (2009). D and ${ }^{18} \mathrm{O}$ isotopes in Atmospheric Precipitation in HongkongArea. Ecology and Environmental Sciences, 18(02):572-577.

38. Zhang Z G , Zhang H P , Sun J C , et al (1987). Environmental isotope study related to groundwater age, flow system and saline water origin in Quaternary aquifer of Hebei plain. Hydrogeology and Engineering Geology, 4:1-6.

Page $12 / 17$ 


\section{Figures}

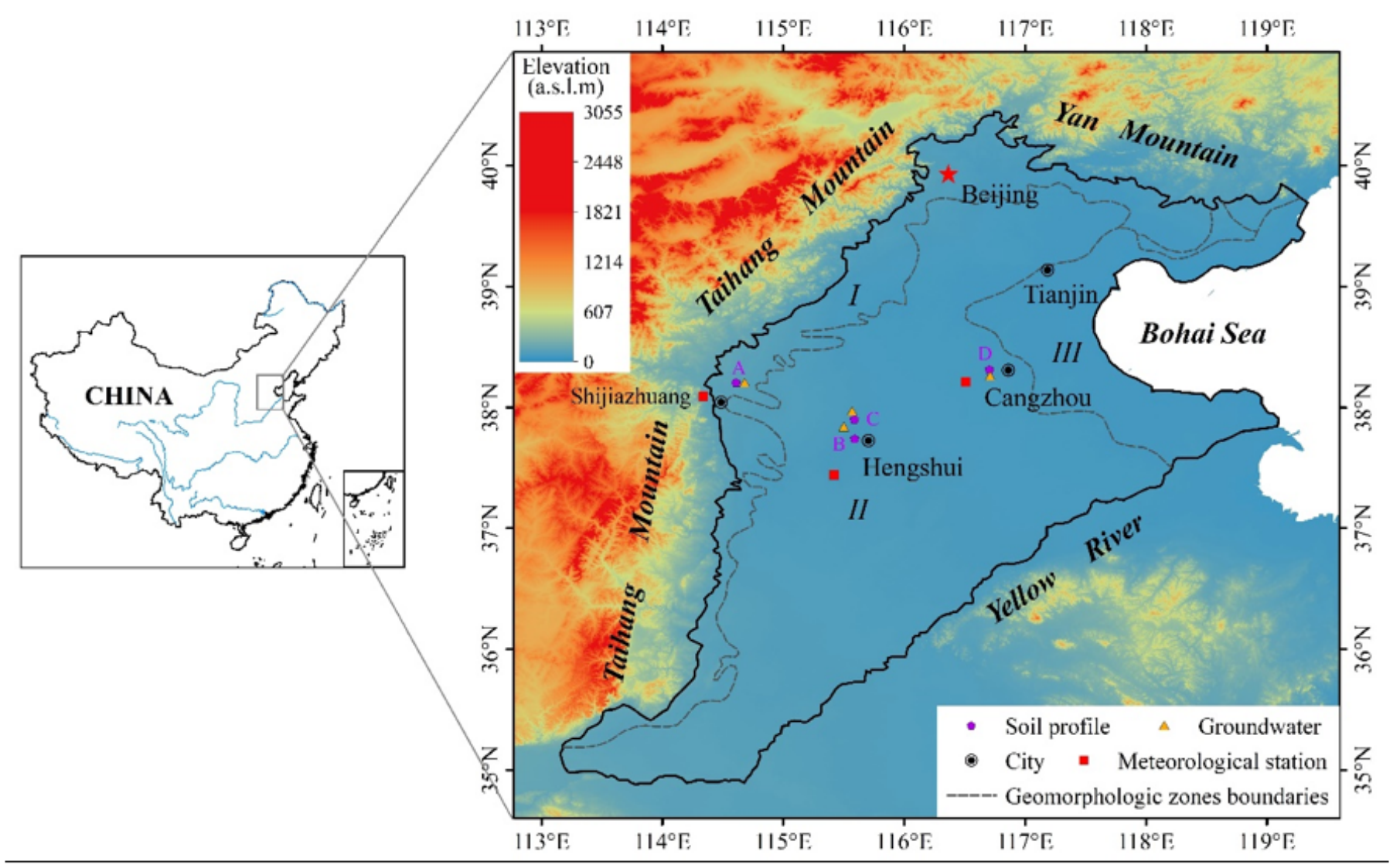

Figure 1

Soil profiles and groundwater samples in the study area. The black solid line represents North China Plain
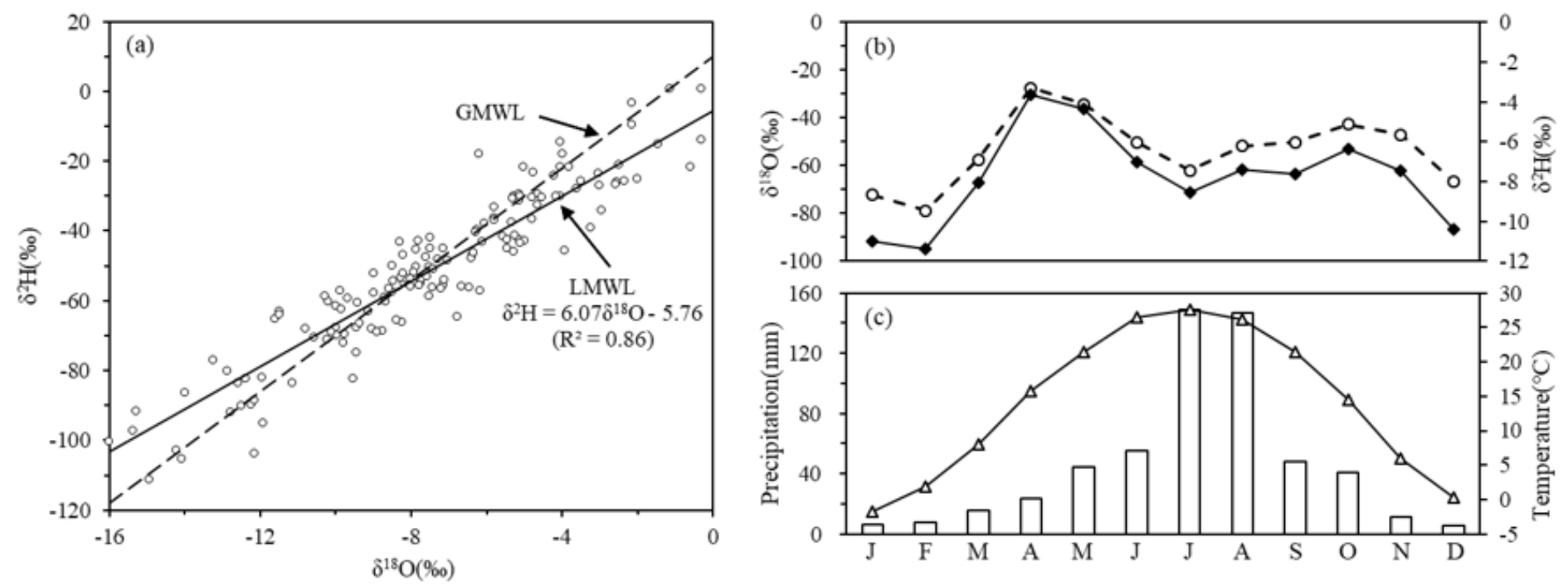

Figure 2

(a): The isotopic compositions of precipitation and LMWL; (b) Mean monthly values of $\delta 180$ and $\delta 2 \mathrm{H}$ of precipitation; (c) Mean monthly values of surface temperature and precipitation (diamonds, circles and triangles represents $\delta 180, \delta 2 \mathrm{H}$ and 
temperature, respectively)

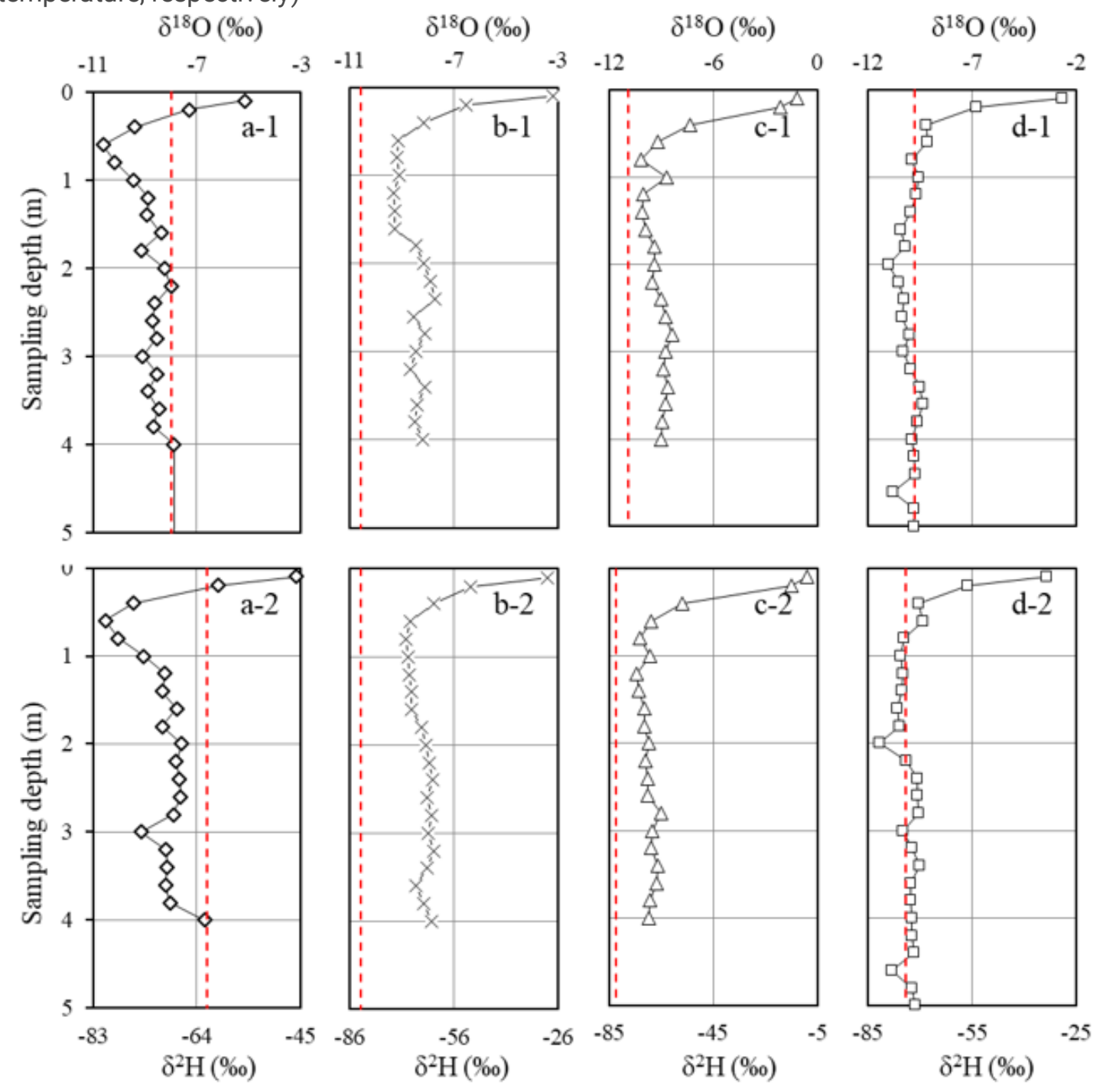

\section{Figure 3}

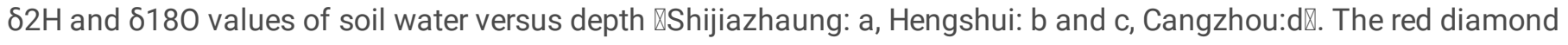
represents the $\delta 2 \mathrm{H}$ and $\delta 180$ values of the nearby groundwater. The red dotted line represents nearby groundwater values 


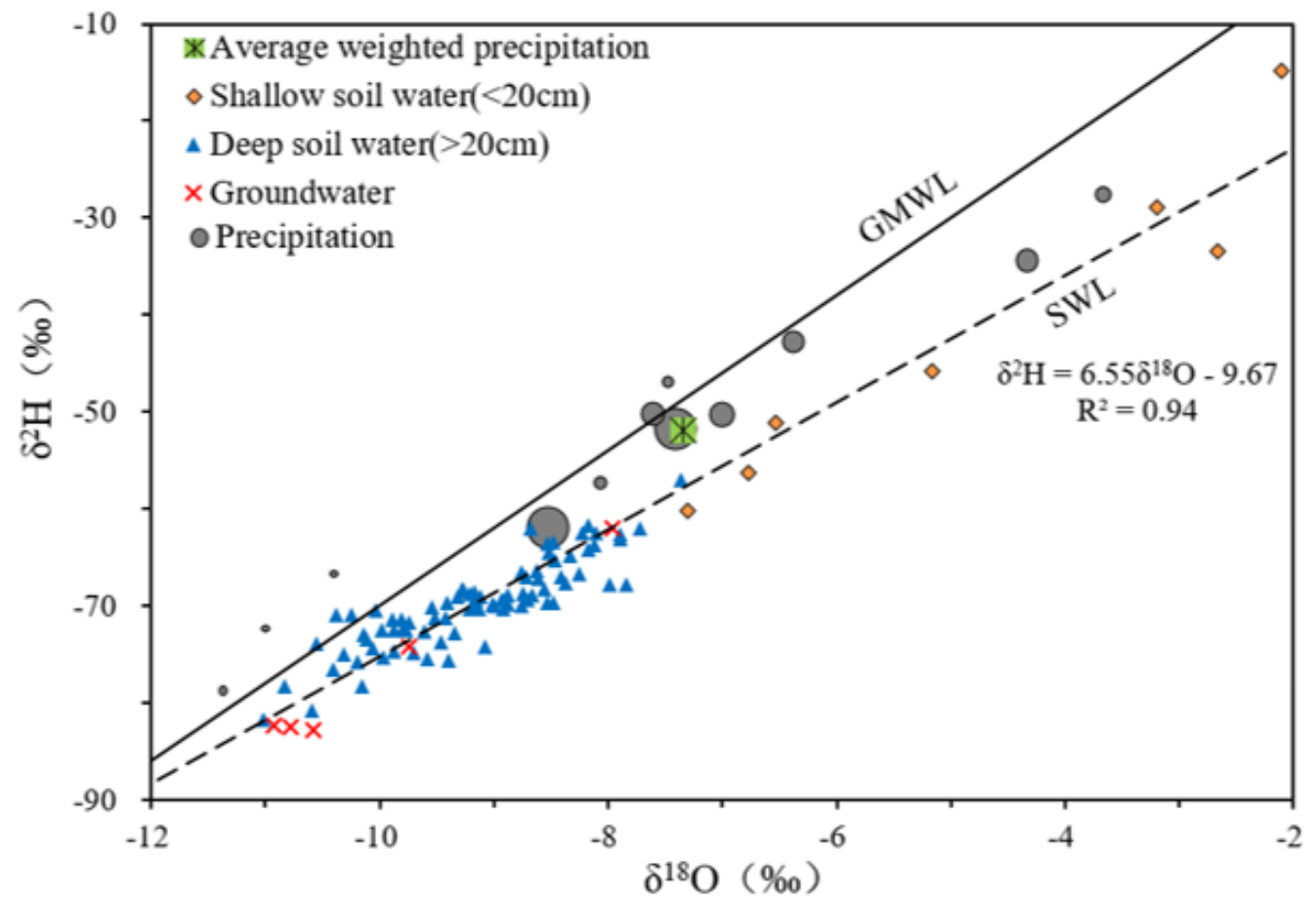

\section{Figure 4}

The relationship of $2 \mathrm{H}$ and 180 between groundwater, soil water and precipitation in North China Plain. Note: SWL represents the evaporation line of soil water 
Chloride-ion Concentration in pore water $(\mathrm{mg} / \mathrm{L})$
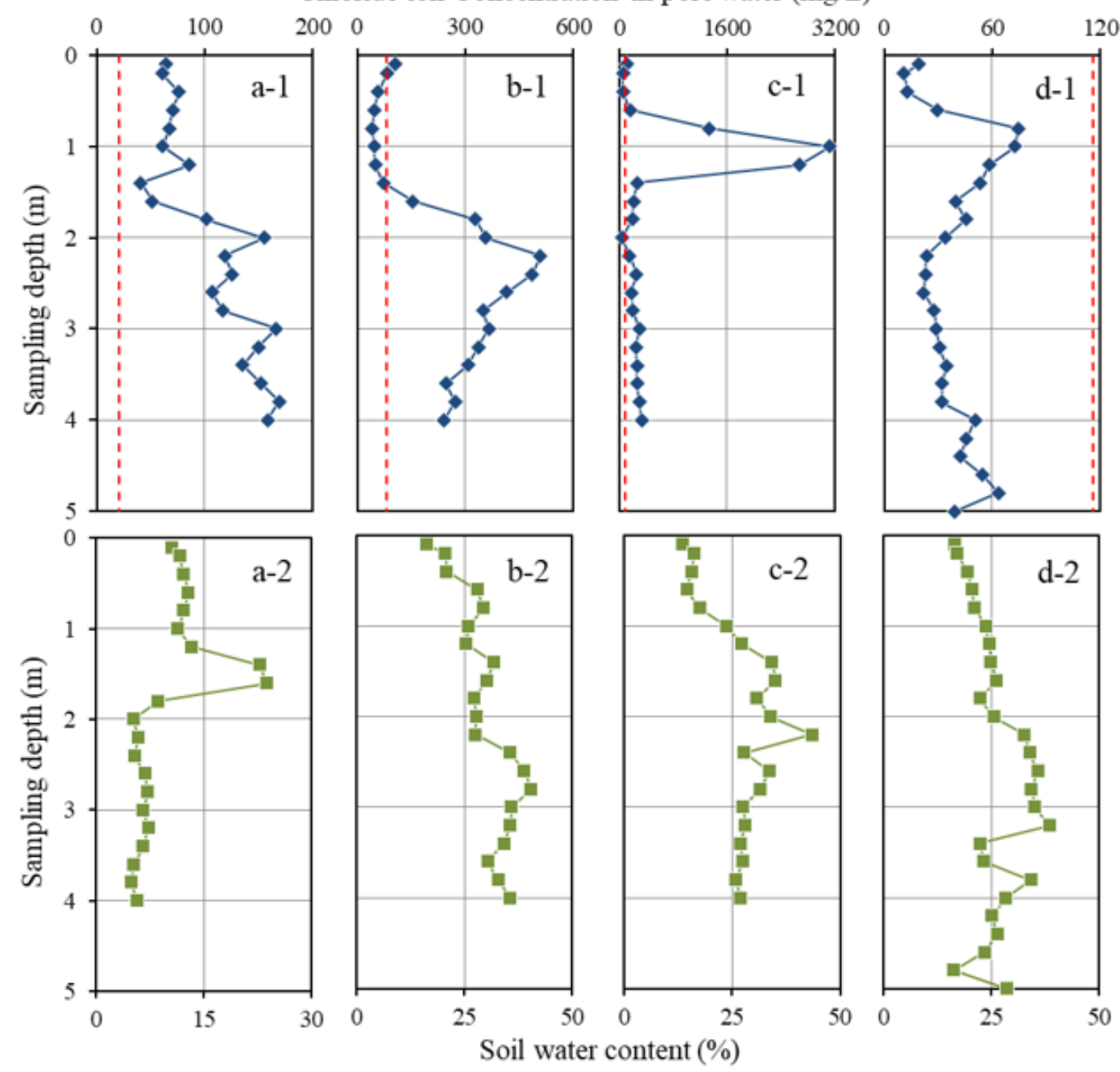

Figure 5

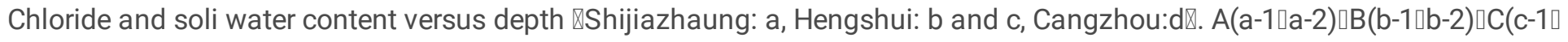
$c-2) \square D(d-1 \square d-2)$

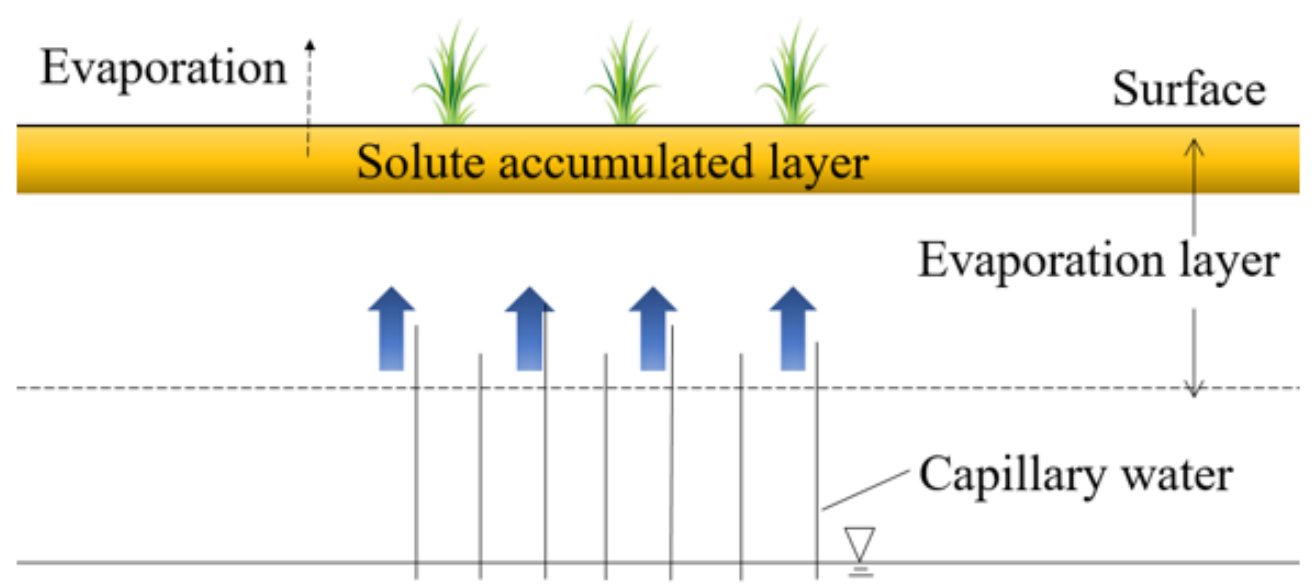

Phreatic aquifer

Figure 6 
The migration process of solute and soil water in the unsaturated zone during the period of salinization (before the 1960s)

Page 17/17 